\title{
Syphilis in riverine communities: prevalence and associated factors*
}

\author{
Sífilis em comunidades ribeirinhas: prevalência e fatores associados \\ Sífilis en comunidades ribereñas: prevalencia y factores asociados
}

How to cite this article:

Nogueira WP, Nogueira MF, Nogueira JA, Freire MEM, Gir E, Silva ACO. Syphilis in riverine communities: prevalence and associated factors. Rev Esc Enferm USP. 2022;56:e20210258. http://doi.org/10.1590/1980-220X-REEUSP-2021-0258

\section{Wynne Pereira Nogueira ${ }^{1}$ \\ (iD) Matheus Figueiredo Nogueira ${ }^{2}$ \\ (iD) Jordana de Almeida Nogueira ${ }^{1}$ \\ (iD) Maria Eliane Moreira Freire ${ }^{1}$ \\ (iD) Elucir $\mathrm{Gir}^{3}$ \\ (iD) Ana Cristina de Oliveira e Silva ${ }^{1}$}

* Extracted from the thesis: "Prevalence and factors associated with syphilis, HIV, hepatitis B and C infection in a riverine communities", Universidade Federal da Paraíba, Programa de Pós-Graduação em Enfermagem, 2020.

${ }^{1}$ Universidade Federal da Paraíba, Programa de Pós-Graduação em Enfermagem, João Pessoa, PB, Brazil.

${ }^{2}$ Universidade Federal de Campina Grande, Centro de Educação e Saúde, Cuité, PB, Brazil.

${ }^{3}$ Universidade de São Paulo, Escola de Enfermagem de Ribeirão Preto, Ribeirão Preto, SP, Brazil.

\begin{abstract}
Objective: To estimate the prevalence of syphilis and associated factors in riverine communities. Method: This is a cross-sectional and analytical study carried out with 250 riverside dwellers living in five communities in the city of João Pessoa, state of Paraíba. Data were collected through interviews and rapid screening tests to investigate syphilis. Bivariate, logistic regression and weight of evidence analysis were performed to identify the association between risk factors and behavior variables and rapid test positivity. Results: The prevalence of syphilis was $11.6 \%$ (95\%CI: 7.5-15.6). Riverside dwellers who have a previous history of Sexually Transmitted Infection (OR 8.00; 95\%CI: 2.76-23.2), history of imprisonment (OR 7.39; 95\%CI: 1.61-33.7) and who reported having more than two sexual partners in the last 12 months (OR 4.31; 95\%CI: $1.55-11.9$ ) were more likely to be positive for syphilis. Conclusion: High prevalence of syphilis among riverside dwellers and the presence of behavioral factors that increase vulnerability to acquiring the infection. The need to invest in preventive and screening strategies for syphilis in populations considered vulnerable is highlighted.
\end{abstract}

\section{DESCRIPTORS}

Syphilis; Vulnerable Populations; Prevalence; Risk Factors; Sexually Transmitted Diseases. 


\section{INTRODUCTION}

Syphilis remains a serious public health problem and is still a challenge to health systems around the world. It is characterized as an infection of chronic progression, caused by the bacteria Treponema pallidum, transmitted mainly through sex (oral, vaginal, and anal), blood, and vertically. It is sometimes asymptomatic, which makes the transmission chain control a challenge - especially if inadequately treated ${ }^{(1)}$.

The World Health Organization (WHO) ${ }^{(2)}$ estimated the occurrence of 6.3 million new cases of syphilis in the world. In Brazil, even though syphilis is curable and there is low-cost treatment available in the public network, data show extremely high growth curves for the disease since it has become a mandatory notification infection.

In the country, in 2019, the detection rate of acquired syphilis was 72.8 cases per 100,000 inhabitants, with notification of 152,915 cases $^{(3)}$. In the state of Paraíba, there was an increase from 8.2 cases in 2015 to 49.1 in 2019, with the capital João Pessoa showing a higher detection rate than the national one: 124.0 cases of acquired syphilis per 100,000 population ${ }^{(4)}$.

Considering these data, the increase in the occurrence of syphilis may be related to the growth in the number of notifications and improvement of the epidemiological surveillance system ${ }^{(5)}$, as well as factors related to social, economic, biological, cultural aspects and, above all, to the population behavioral changes ${ }^{(5-6)}$.

Furthermore, the prevalence of syphilis worldwide in key populations is high, especially in men who have sex with men (MSM), sex workers, and injecting drug users. However, the incidence of infection also has a dissemination character in populations considered vulnerable, which represent communities with social, economic, and cultural weaknesses that increase the risk of contamination of Sexually Transmitted Infections (STIs) ${ }^{(7-8)}$.

Low adherence to condom use, multiple partners, and injecting drug use may represent individual vulnerabilities related to risky sexual behaviors that increase the incidence of syphilis ${ }^{(7,9)}$. In addition, the influence of socioeconomic aspects, such as low education, low income, and difficult access to health services, are also determining factors for maintenance and/or the emergence of an infection ${ }^{(10)}$.

In this context, the riverside dwellers are included, as they have situations of vulnerability that make them weak regarding issues related to morbidity and health care, especially sexual health $^{(11)}$. Riverine populations in the urban area of northeastern Brazil are those who live on the riversides of the main rivers crossing the cities, in a space of subnormal agglomerations, difficult access, with inadequate living conditions and lack of basic sanitation sewage systems ${ }^{(12)}$.

Thus, they are individuals exposed to determinants and conditions related to the health-disease process, such as low socioeconomic conditions, limited access to health services, as well as limitations related to geographic and organizational factors $^{(13)}$.

In Brazil, data on the prevalence of STIs in riverside populations are scarce. For these people, issues related to waterborne diseases and injuries predominate when it comes to knowledge production. Therefore, knowing the prevalence of syphilis and the factors associated with its acquisition can contribute to the planning of health strategies and actions that minimize the potential factors and risk behaviors determining the infection in this population group, as well as contributing to the expansion of knowledge about the epidemiological profile of this population.

Given the above, this study aimed to estimate the prevalence of syphilis and associated factors in riverine communities in the state of Paraíba.

\section{METHOD}

\section{Design of Study}

This is a cross-sectional and analytical study.

\section{LOCAL}

The study was carried out in five riverside communities - São José, Tito Silva, Porto do Capim, São Rafael and Comunidade do "S" - located in the municipality of João Pessoa and in surrounding areas in the state of Paraíba.

\section{Population}

The target population consisted of residents of the aforementioned riverside communities. Individuals aged 18 years or over were included, and those who had more than one residence, where at least one of them was not located in the investigated community, were excluded.

For the composition of the sample, 11,498 individuals were considered, which corresponds to the sum of the total number of residents of these communities: São Rafael $(n=1,800)$, São José $(\mathrm{n}=7,078)$, Tito Silva $(\mathrm{n}=1,140)$, Porto do Capim $(\mathrm{n}=550)$, and Comunidade do $\mathrm{S}(\mathrm{n}=930)$. To determine the sample size, a confidence interval of $95 \%$, a desirable margin of error of $5.4 \%$, and an estimated frequency of $26.15 \%$ were assumed $^{(14-15)}$. Thus, the study sample consisted of 250 individuals.

\section{Data Collection}

Data collection was carried out from June to October 2019. The articulation for the operationalization of the study was made through the community's family health teams with the support of the Community Health Agents $(A C S)$. Eligible individuals were invited to participate in the research through prior contact carried out by the ACSs. Those who accepted were informed about the importance of the study, the objectives, risks and benefits related to their participation. Soon after, an individual and private interview was carried out at support sites within the communities.

Information was collected from a structured questionnaire, adapted from the instrument used in the Survey of Knowledge, Attitudes and Practices in the Brazilian Population ${ }^{(16)}$, covering sociodemographic data and possible behavioral factors for the acquisition of syphilis, as well as the use of the Alcohol Use Disorders Identification Test (AUDIT). AUDIT is an instrument developed by $\mathrm{WHO}^{(17)}$ and used to measure the pattern of alcohol use in the last 12 months by an individual. The riverside dwellers who obtained scores from 0 to 7 on the 
AUDIT were considered low-risk consumers and those who obtained results equal to or above 8 were classified in a pattern of harmful and problematic alcohol consumption (risk, harmful, and of probable dependence consumption).

After the interview, the participants were invited to perform the rapid screening test for syphilis, which in this study was the lateral flow immunochromatographic assay (Bioclin: Quibasa Química Basica, Brazil), responsible for the qualitative detection of anti-Treponema pallidum total antibodies, with the serological collection obtained through digital pulp blood sampling. For its performance, all the guidelines from the manufacturer and the Ministry of Health protocol were strictly followed ${ }^{(18)}$, including pre-test and post-test counseling, individually and privately, regardless of a positive or negative result for syphilis.

Participants with reactive results were guided and referred to the city's STIs reference service for monitoring and free individual treatment. The team of interviewers responsible for the rapid testing and the interview consisted of graduate and undergraduate students and health professionals (nurses), who were previously trained and qualified by technicians from the State Health Department, as directed by the Ministry of Health ${ }^{(18)}$.

\section{Data Analysis and Treatment}

The collected data were double-entered into a Microsoft Excel 2010 spreadsheet and imported into the statistics software SPSS version 20 to perform descriptive and inferential analyses. The prevalence of syphilis, investigated according to positivity for the rapid test, was calculated considering a 95\% confidence interval $(95 \% \mathrm{CI})$. The positivity of the rapid test for syphilis was considered as a dependent variable.

To investigate the association between sociodemographic and behavioral variables and the positivity of the rapid test for syphilis, a bivariate analysis was performed, carried out using Pearson's chi-square test and Fisher's exact test. The variables that presented a significance level of $\mathrm{p}<0.20$ were simultaneously included in the binary logistic regression model, generating the odds ratio with $95 \% \mathrm{CI}$. In the final model, the variables showing a statistically significant association with $\mathrm{p} \leq 0.05$ were considered.

After applying the logistic regression model, the Weight of Evidence analysis was performed to determine the strength of the relationship between the independent and dependent variables, considering that, in an Information Value (IV) $<0.02$, the predictor is too weak (not useful); from 0.02 to $<0.1$, the predictor has a weak relationship; from 0.1 to 0.3 , an average strength ratio; and $>0.3$, the predictor has a strong relationship ${ }^{(19)}$.

\section{EThical Aspects}

All ethical precepts that guide the research involving human beings, established in Resolution No. 466/2012 of the National Health Council, were followed, and all participants signed the Free Informed Consent Term (FICT). The research was approved by the Research Ethics Committee of the Universidade Federal da Paraíba with opinion no. 3.340.273/2019.

\section{RESULTS}

Of the 250 riverside dwellers interviewed in the study, there was a predominance of females, 170 (68.0\%); from the age group between 18 and 39 years, 108 (43.2\%); and with up to eight years of schooling, 155 (62.0\%). As for marital status, most participants declared themselves married or in cohabitation, $160(64.0 \%)$, and with a monthly family income of up to 1.5 minimum wages, 208 (83.2\%). Regarding the riverside communities, 154 (61.6\%) individuals live in the community São José, 39 (15.6\%) in São Rafael, 25 (10.0\%) in Tito Silva, 20 (8.0\%) in Comunidade do S, and 12 (4.8\%) individuals in Porto do Capim.

The prevalence of syphilis, investigated according to positivity of the rapid test, was $11.6 \%$ (95\%CI: 7.5-15.6), which corresponds to 29 riverside dwellers who tested positive for this infection.

Table 1 shows the bivariate analyses of sociodemographic characteristics and their association with rapid syphilis test positivity.

In the association between the variables of the main risk behaviors associated with the positivity of the rapid test for syphilis, the number of sexual partners $(\mathrm{p}=0.012)$, the previous history of STI ( $<$ 0.001), smoking $(p=0.020)$, AUDIT score $(\mathrm{p}=0.023)$, and history of imprisonment $(\mathrm{p}=0.026)$ were statistically significant (Table 2).

Logistic regression analysis showed that riverside dwellers with a previous history of STIs (OR 8.00; 95\%CI: 2.76-23.2), history of imprisonment (OR 7.39; 95\%CI: 1.61-33.7), and with a report of more than two sexual partners in the last

Table 1 - Association between sociodemographic characteristics and the positivity of the rapid test for syphilis performed in residents of riverside communities - João Pessoa, PB, Brazil, 2019.

\begin{tabular}{|c|c|c|c|}
\hline \multirow[b]{2}{*}{ Variables } & \multicolumn{2}{|c|}{ Rapid syphilis test } & \multirow[b]{2}{*}{ p-value } \\
\hline & $\begin{array}{c}\text { Positive } \\
(\mathrm{n}=29) \mathrm{n}(\%)\end{array}$ & $\begin{array}{c}\text { Negative } \\
(\mathrm{n}=221) \mathrm{n}(\%)\end{array}$ & \\
\hline \multicolumn{4}{|l|}{ Sex } \\
\hline Male & $11(13.8)$ & $69(86.2)$ & \multirow{2}{*}{0.460} \\
\hline Female & $18(10.6)$ & $152(89.4)$ & \\
\hline \multicolumn{4}{|l|}{ Age } \\
\hline 18 to 39 years old & $12(11.1)$ & $96(88.9)$ & \multirow{3}{*}{0.601} \\
\hline 40 to 59 years old & $10(10.2)$ & $88(89.8)$ & \\
\hline$\geq 60$ years old & 7 (15.9) & $37(84.1)$ & \\
\hline \multicolumn{4}{|l|}{ Level of education } \\
\hline$\leq 8$ years of study & $19(12.3)$ & $136(87.7)$ & \multirow{2}{*}{0.670} \\
\hline$>8$ years of study & $10(10.5)$ & $85(89.5)$ & \\
\hline \multicolumn{4}{|l|}{ Marital status } \\
\hline $\begin{array}{l}\text { Married/Consensual } \\
\text { Union }\end{array}$ & $14(8.8)$ & $146(91.2)$ & \multirow{2}{*}{0.262} \\
\hline $\begin{array}{l}\text { Single/Separated/ } \\
\text { Widowed }\end{array}$ & $15(16.7)$ & $75(83.3)$ & \\
\hline \multicolumn{4}{|l|}{ Monthly income } \\
\hline$\leq 1$ minimum wage & $18(10.5)$ & $154(89.5)$ & \multirow{2}{*}{0.401} \\
\hline$>1$ minimum wage & $11(14.1)$ & 67 (85.9) & \\
\hline
\end{tabular}


Table 2 - Association between the main risk behaviors with the positivity of the rapid test for syphilis performed in residents of riverside communities in João Pessoa, PB, Brazil, 2019.

\begin{tabular}{|c|c|c|c|}
\hline \multirow[b]{2}{*}{ Variables } & \multicolumn{2}{|c|}{ Rapid syphilis test } & \multirow[b]{2}{*}{ p-value* } \\
\hline & $\begin{array}{c}\text { Positive } \\
(\mathbf{n}=29) \\
\text { n }(\%)\end{array}$ & $\begin{array}{c}\text { Negative } \\
(\mathrm{n}=221) \\
\mathrm{n}(\%)\end{array}$ & \\
\hline Age of first sexual intercourse & & & $0.073^{* *}$ \\
\hline$\leq 15$ years & $18(16.1)$ & $94(83.9)$ & \\
\hline$>15$ years & $11(8.0)$ & $127(92.0)$ & \\
\hline $\begin{array}{l}\text { Number of sexual partners in } \\
\text { the last } 12 \text { months }\end{array}$ & & & $0.012^{* *}$ \\
\hline 0 to 1 partner & $16(8.5)$ & $172(91.5)$ & \\
\hline 2 or more partners & $13(21.0)$ & $49(79.0)$ & \\
\hline $\begin{array}{l}\text { Sexual intercourse with a } \\
\text { person of the same sex }\end{array}$ & & & $0.079^{+}$ \\
\hline Yes & $5(23.8)$ & $16(76.2)$ & \\
\hline No & $24(10.5)$ & 205 (89.5) & \\
\hline Knows male condom & & & $0.265^{+}$ \\
\hline Yes & $25(10.9)$ & $205(89.1)$ & \\
\hline No & $4(20.0)$ & $16(80.0)$ & \\
\hline Knows the female condom & & & $1.000^{* *}$ \\
\hline Yes & $19(11.4)$ & $147(88.6)$ & \\
\hline No & $10(11.9)$ & $74(88.1)$ & \\
\hline $\begin{array}{l}\text { Condom use in the last sexual } \\
\text { intercourse* }\end{array}$ & & & $0.402^{* *}$ \\
\hline Yes & $6(15.4)$ & $33(84.6)$ & \\
\hline No & $18(10.4)$ & 155 (89.6) & \\
\hline $\begin{array}{l}\text { Sexual intercourse with a sex } \\
\text { worker }\end{array}$ & & & $0.777^{+}$ \\
\hline Yes & $5(14.3)$ & $30(85.7)$ & \\
\hline No & $24(11.2)$ & $191(88.8)$ & \\
\hline $\begin{array}{l}\text { Received money or paid in } \\
\text { exchange for sex }\end{array}$ & & & $0.051^{* *}$ \\
\hline Yes & $8(21.6)$ & $29(78.4)$ & \\
\hline No & $21(9.9)$ & $192(90.1)$ & \\
\hline $\begin{array}{l}\text { Sexual intercourse with a } \\
\text { partner met through } \\
\text { cell phone call }\end{array}$ & & & $1.000^{+}$ \\
\hline Yes & $2(15.4)$ & $11(84.6)$ & \\
\hline No & $27(11.4)$ & $210(88.6)$ & \\
\hline Previous history of STIs & & & $<0.001 * *$ \\
\hline Yes & $14(26.9)$ & $38(73.1)$ & \\
\hline No & $15(7.6)$ & $183(92.4)$ & \\
\hline Smoking & & & $0.020^{* *}$ \\
\hline Yes & $13(19.4)$ & $54(80.6)$ & \\
\hline No & $16(8.7)$ & $167(91.3)$ & \\
\hline Illegal drug use & & & $0.071^{* *}$ \\
\hline Yes & $11(18.0)$ & $50(82.0)$ & \\
\hline No & $18(9.5)$ & $171(90.5)$ & \\
\hline AUDIT score & & & $0.023^{* *}$ \\
\hline$<8$ points & $22(9.9)$ & $201(90.1)$ & \\
\hline$\geq 8$ points & $7(25.9)$ & $20(74.1)$ & \\
\hline History of imprisonment & & & $0.026^{+}$ \\
\hline Yes & $5(31.2)$ & $11(68.8)$ & \\
\hline No & $24(10.3)$ & $210(89.7)$ & \\
\hline
\end{tabular}

* Those who had sexual intercourse in the last 12 months; ** Chi-square test; ${ }^{\dagger}$ Fisher's exact test.
Table 3 - Odds ratios for the significant variables identified by logistic regression for a positive rapid test result for syphilis in riverside communities in João Pessoa, PB, Brazil, 2019.

\begin{tabular}{lccc}
\hline Variables & Odds ratio & $\mathbf{9 5 \%} \mathbf{C l}$ & p-value* \\
\hline Previous history of STIs & 8.00 & $2.76-23.2$ & $<\mathbf{0 . 0 0 1 *}$ \\
$\begin{array}{l}\text { History of imprisonment } \\
\begin{array}{l}\text { More than two sexual partners in } \\
\text { the last 12 months }\end{array}\end{array}$ & 7.39 & $1.61-33.7$ & $\mathbf{0 . 0 1 0 *}$ \\
\hline
\end{tabular}

$95 \% \mathrm{Cl}: 95 \%$ confidence interval; ${ }^{*}$ Significant result with $\mathrm{p}<0.05$.

12 months (OR 4.31; 95\%CI: 1.55-11.9) are approximately eight, seven and four times more likely to have a positive rapid test result for syphilis, respectively (Table 3 ).

After applying the logistic regression model, the Weight of Evidence analysis was performed, as shown in Figure 1.

The $\mathrm{WoE}$ analysis showed that the same variables detected by the logistic regression model also showed evidence of being associated with the outcome: multiple partners $(\mathrm{IV}=0.237)$, history of imprisonment $(\mathrm{IV}=0.169)$ and, in particular, the variable related to the fact of having a previous history of STIs $(\mathrm{IV}=0.467)$.

\section{DISCUSSION}

The increase in syphilis cases in Brazil shows a growing trend over the last ten years ${ }^{(3)}$. However, investigation of the infection in riverside populations is still scarce, especially in those living in the Northeast region. The few studies available on STIs in this population group were carried out in the Brazilian Amazon ${ }^{(8,20-21)}$. Thus, this study represents one of the first on the national scenario to estimate the prevalence of syphilis in the riverside population living in urban areas.

Due to the lack of data on the estimated prevalence of syphilis and factors associated with the infection in these individuals, the comparison with riverside realities will be limited. Thus, for comparative analyses, other populations characterized as vulnerable in health-related aspects will be considered.

As for the sociodemographic aspects of the 250 residents interviewed in the riverside communities, it was observed that most have up to eight years of education and an income of up to 1.5 minimum wages. The low education and low income found are common characteristics in riverside populations from other locations $^{(12-13,21)}$.

In this study, through the positivity of rapid tests, it was possible to estimate a prevalence of syphilis of $11.6 \%$ (95\%CI: 7.5-15.6) in the riverside population investigated. This identified rate was higher than the national estimate of syphilis $^{(3)}, 0.5 \%$ (95\%CI: 0.4-0.6). Furthermore, in Paraiba, in $2019,1,973$ cases of acquired syphilis were reported, with an increase in the detection rate from 39.7 cases to $49.1^{(4)}$. In addition, it is observed that studies involving other vulnerable groups had a lower prevalence compared to the population of this research ${ }^{(20,22)}$.

In this perspective, a study carried out with 153 women in the Tapajós region, in the Brazilian Amazon, showed a global prevalence of syphilis of 3.3\% (95\% CI: $1.40-7.42)^{(20)}$. In the same region, a survey carried out with 45,967 indigenous people showed a prevalence of $1.82 \%$ (95\%CI: $1.69-1.94)^{(22)}$ for this 


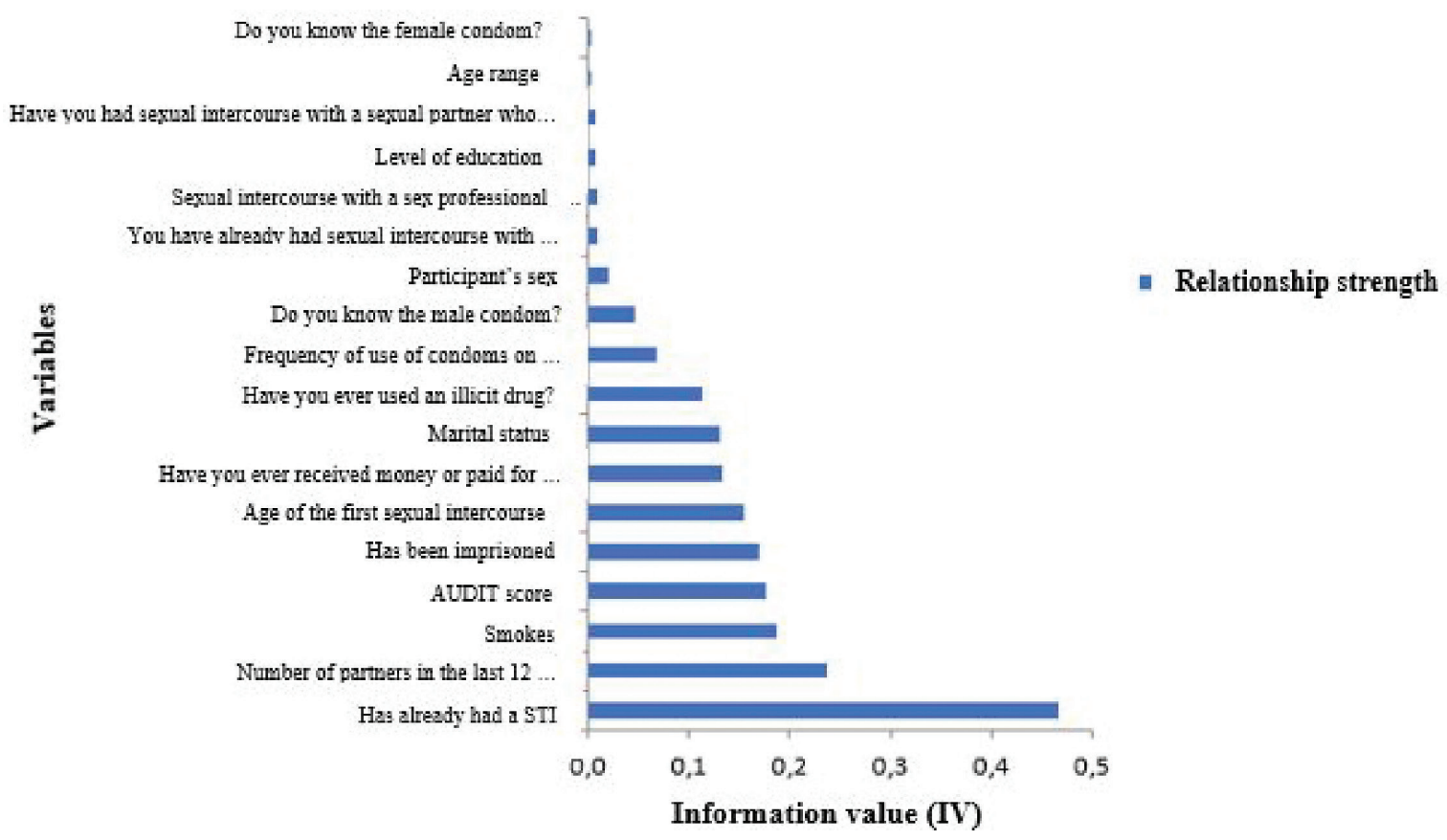

Figure 1 - Result of the outcome analysis via classification by Information Value (IV) generated by the WoE. João Pessoa, PB, Brazil, 2019.

infection, which corresponds to low prevalence compared to the riverside population. Another investigation carried out with 416 illegal miners in French Guiana found a prevalence of $11.5 \%$ (95\%CI: 8.5-14.6) for syphilis ${ }^{(23)}$, prevalence similar to the population of this research.

Thus, the result of the present research shows a high prevalence of syphilis in riverside dwellers, which is concerning. In addition to the fact that the infection has asymptomatic characteristics, encouraging silent propagation, the population has limited access to health services, which hinders the diagnosis and treatment. In addition to these conditions, the research also shows factors and behaviors among riverside dwellers that may favor the spread of syphilis.

It is observed that, although the sociodemographic characteristics of riverside dwellers have not been statistically significantly associated with the prevalence of syphilis, it is believed that education and economic status are determining factors in the health-disease process. Individuals having low education and low economic conditions reflect in less access to information about health care, risk perception and prevention of multiple diseases ${ }^{(10,24)}$. Therefore, they are individuals considered to be more susceptible to acquiring STI.

Furthermore, the analysis of risky sexual behaviors showed that the multiplicity of partners increases by 4.3 (95\%CI: 1.55-11.9) the chance that riverside dwellers present a positive rapid syphilis test. It is known that the multiplicity of partners is a risk behavior widely known for the risk of acquiring an $S T I^{(25)}$.

Similar data was found in a study carried out in municipalities in the state of Goiás, Brazil, with 481 homeless men, in which the multiplicity of partners was statistically associated with a positive result for syphilis ${ }^{(26)}$. Such behavior may be related to the early beginning of sexual life and the influence of socioeconomic issues $^{(10,27)}$. In addition, the lack of knowledge and low adherence to condom use can favor the acquisition and spread of the infection ${ }^{(27)}$.

This fact is seen in the study population, as the results show that $69.2 \%$ of riverside dwellers reported not having used a condom in the last sexual intercourse. This may be a consequence of the low educational level of individuals residing in these communities, since educational issues, including the level of understanding and self-care capacity, can influence adherence to barrier methods and less concern with health care $^{(27)}$.

In this investigation, $6.4 \%$ of the riverside dwellers reported a history of imprisonment. It is essential to address this data, since contexts directly linked to social vulnerability - such as poverty, unemployment and socioeconomic exclusion - can promote the increase in crime in the country ${ }^{(28)}$, which can be observed in riverside realities, thus leading to the need to implement public policies for vulnerable populations.

Moreover, this risk factor was associated with the studied outcome. Riverside dwellers who reported a history of imprisonment at some point in their lives were approximately seven times more likely (OR 7.39; 95\%CI: 1.61-33.7) to have a positive rapid test result for syphilis. Research identifies that prisons provide a favorable epidemiological scenario for increasing STI rates due to the prison population's high-risk behavior, such as sexual intercourse without condom use, sexual violence, in addition to sharing of sharp objects, especially for the use of injecting drugs ${ }^{(9,29)}$.

In the present study, the previous history of STIs was strongly associated with the outcome, according to the WoE. The results also showed that riverine populations who reported a previous history of STIs are eight times more likely (OR 8.00; 95\% CI: 2.76-23.2) to have a positive result of the rapid test for syphilis. A similar association was also found in studies with other vulnerable populations ${ }^{(7,30)}$. 
A population-based survey conducted in rural China, with $2,044,126$ women, showed an association between a previous history of STIs and a positive result for syphilis (OR 27.17, 95\%CI: 20.44-36.11) ${ }^{(30)}$. A study carried out with 1,405 homeless people in the state of São Paulo also showed this association (OR 2.6; 95\%CI 1.7-4.0) (7).

Late diagnosis, inadequate treatment, nonuse of condoms, multiple partners, the presence of wounds in the genital region, untreated sexual partners, reinfection and possible drug resistance are factors that may be related to the previous presence of STI in this population and, consequently, a greater vulnerability to the acquisition of syphilis ${ }^{(25-27)}$. It is also important to highlight that the presence of STIs increases by 18 times the risk of a person being infected with HIV, an infection for which there is no cure, so that health authorities focus greater efforts on screening, prevention, and control of the virus.

This strong association shows that making a timely diagnosis and proper treatment are essential. Biomedical, behavioral, and structural interventions centered in the specificity of vulnerable populations are essential for an effective response to the syphilis and other STIs epidemic.

An important fact refers to the high prevalence of syphilis in riverside dwellers of dry land (urban area), which is higher than the state and even national prevalence. This result reinforces the presence of social and health vulnerabilities that favor the spread of STIs among riverside dwellers and that actions aimed at the specificities of population groups in the context of STIs have to be effective.

As for the limitations of this research, the design of the cross-sectional study does not allow making causal inferences; however, it allows exploring associations and raising hypotheses. Another limitation was the estimate of syphilis prevalence investigated through the rapid test, since it does not provide information of diagnosis of active syphilis or serological scarring in previously treated people. Moreover, the situational diagnosis of the population is the first step to propose interventions and the rapid test represents a rapid diagnostic tool to be used in specific situations, such as in places with difficult access to health services and in vulnerable population segments, besides providing information to health managers for possible interventions related to preventive measures and the epidemiological profile of morbidity in a given population.

\section{CONCLUSION}

The research provides evidence of the high prevalence of syphilis, according to rapid test positivity, in riverine communities, and that a previous history of STI, history of imprisonment, and multiple partners were behavioral factors associated with a greater chance of riverine populations to have a positive rapid syphilis test.

Riverine populations present several behavioral and social aspects that increase their vulnerability to the acquisition of syphilis. These are situations that turn them weak regarding issues related to morbidity, health access and care, especially those related to sexual and reproductive health. In this scenario, disproportionality in relation to the general population requires a differentiated and combined response among those responsible for fighting syphilis, HIV/AIDS, and other STIs, mainly to ensure universal and equitable access.

Therefore, it is expected that the findings presented contribute to public health actions, given the need to ensure access of vulnerable populations to health services, with the work of nurses in promoting preventive and control strategies, along with early diagnosis and adequate therapeutic adherence. It is also important that they support further research that can broaden the knowledge about riverine populations and their vulnerabilities regarding the acquisition of STIs.

\section{RESUMO}

Objetivo: estimar a prevalência de sífilis e fatores associados em comunidades ribeirinhas. Método: estudo transversal e analítico realizado com 250 ribeirinhos residentes em cinco comunidades no município de João Pessoa, estado da Paraíba. Os dados foram coletados por meio de entrevista e testes rápidos de triagem para investigação da sífilis. Realizaram-se análise bivariada, de regressão logística e análise do peso da evidência (Weight of Evidence) para identificar a associação entre as variáveis de fatores e de comportamento de risco e a positividade do teste rápido. Resultados: a prevalência de sífilis foi de 11,6\% (IC95\%: 7,5-15,6). Ribeirinhos que possuem história prévia de Infecção Sexualmente Transmissível (OR 8,00; IC95\%: 2,76-23,2), histórico de prisão (OR 7,39; IC95\%: 1,61-33,7) e que relataram ter mais de dois parceiros sexuais nos últimos 12 meses (OR 4,31; IC95\%: 1,55-11,9) apresentaram maiores chances de apresentar resultado positivo para sífilis. Conclusão: alta prevalência de sífilis entre os ribeirinhos e presença de fatores comportamentais que aumentam a vulnerabilidade à aquisição da infecção. Reforça-se a necessidade do investimento de estratégias preventivas e de rastreamento de sífilis em populações consideradas vulnerabilizadas.

\section{DESCRITORES}

Sífilis; Populações vulneráveis; Prevalência; Fatores de Risco; Doenças Sexualmente Transmissíveis.

\section{RESUMEN}

Objetivo: estimar la prevalencia de sífilis y factores asociados en comunidades ribereñas. Método: estudio transversal y analítico realizado con 250 ribereños residentes en cinco comunidades en el municipio de João Pessoa, Paraíba, Brasil. Los datos fueron recolectados por medio de entrevista y pruebas serológicas rápidas de triaje para investigación de sífilis. Se realizaron análisis bivariado, análisis de regresión logística y análisis del peso de la evidencia (Weight of Evidence) para identificar la asociación entre las variables de factores y de comportamiento de riesgo y la positividad de la prueba serológica rápida. Resultados: la prevalencia de sífilis fue un 11,6\% (IC95\%: 7,5-15,6). Ribereños que poseen historia anterior de Infección Sexualmente Transmisible (OR 8,00; IC95\%: 2,76-23,2), histórico de cárcel (OR 7,39; IC95\%: 1,61-33,7) y que relataron tener más de dos parejas sexuales en los últimos 12 meses (OR 4,31; IC95\%: 1,55-11,9) demostraron mayores riesgos de presentar resultado positivo para la enfermedad. Conclusión: alta prevalencia de sífilis entre los ribereños y presencia de factores comportamentales que aumentan la vulnerabilidad a la adquisición de la infección. Se refuerza la necesidad de inversión en estrategias preventivas y de identificación de sífilis en poblaciones consideradas vulnerables. 
DESCRIPTORES

Sífilis; Poblaciones Vulnerables; Prevalencia; Factores de Riesgo; Enfermedades de Transmisión Sexual.

\section{REFERENCES}

1. Lasagabaster MA, Guerra LO. Syphilis. Enferm Infecc Microbiol Clin. 2019;37(6):398-404. DOI: https://doi.org/10.1016/j.eimc.2018.12.009

2. World Health Organization [Internet]. Geneva: WHO; 2019 [cited 2020 July 02]. Sexually transmitted infections (STIs). Key facts. Available from: https://www.who.int/en/news-room/fact-sheets/detail/sexually-transmitted-infections-(stis)

3. Brasil, Secretaria de Vigilância em Saúde, Ministério da Saúde. Boletim Epidemiológico Especial - Sífilis 202 [Internet]. Brasília: Ministério da Saúde; 2020 [cited 2021 Apr 20]. Available from: https://www.gov.br/saude/pt-br/media/pdf/2020/outubro/29/BoletimSfilis2020especial.pdf

4. Secretaria de Estado da Saúde da Paraíba, Gerência Executiva de Vigilância em Saúde. Boletim Epidemiológico nº 02 [Internet]. João Pessoa; 2020 [cited 2021 Apr 20]. Available from: https://paraiba.pb.gov.br/diretas/saude/arquivos-1/vigilancia-em-saude/boletim-sifilis-2020-2.pdf

5. Santos MM, Lopes AKB, Roncalli AG, Lima KC. Trend of syphilis in Brazil: a growth Portrait os the treponemic epidemic. PLoS ONE. 2020;15(4): 1-11. DOI: https://doi.org/10.1371/journal.pone.0231029

6. Chang BA, Pearson WS, Owusu-Edusei Jr K. Correlates of county-level nonviral sexually transmitted infection hot spots in the US: application of hot spot analysis and spatial logistic regression. Ann Epidemiol. 2017;27(4):231-7. DOI: https://doi.org/10.1016/j.annepidem.2017.02.004

7. Pinto VM, Tancredi MV, Alencar HDR, Camolesi E, Holcman MM, Grecco JP, et al. Prevalence of syphilis and associated factors in homeless people of Sao Paulo, Brazil, using a rapid rest. Rev Bras Epidemiol. 2014;17(2):341-54. DOI: https://doi.org/10.1590/1809-4503201400020005ENG

8. Coulibaly IGS, Morais JC, Marsiglia RMG, Montanari PM. Sexually transmitted diseases and the vulnerability of the population in the Alto Solimões region, in Amazonas, Brazil. Saúde e Sociedade. 2017;26(1):51-60. DOI: http://dx.doi.org/10.1590/s0104-12902017162948

9. Silva PAS, Gomes LA, Amorim-Gaudêncio C, Lima KPN, Medeiros LB, Nogueira JA. Syphilis in women coming out of the prison system: prevalence and associated factors. Rev RENE. 2018;19:e3321. DOI: https://doi.org/10.15253/2175-6783.2018193321

10. Macêdo VC, Lira PIC, Frias PG, Romaguera LMD, Caires SFF, Ximenes RAA. Risk factors for syphilis in women: case-control study. Rev Saude Publica. 2017;51:78. DOI: https://doi.org/10.11606/s1518-8787.2017051007066

11. Parmejiani EP, Queiroz ABA, Pinheiro AS, Cordeiro EM, Moura MAV, Paula MBM. Sexual and reproductive health in riverine communities: integrative review. Rev Esc Enferm USP. 2021;55:e03664. DOI: https://doi.org/10.1590/S1980-220X2019033103664

12. Assunção MM, Barreto LN, Addum FM, Feitosa AC, Rodrigues ZMR. Socioenvironmental diagnostic of a riverside urban population of the Pindaré river, Maranhão State. InterEspaço. 2016;2(7):96-114. DOI: http://dx.doi.org/10.18764/2446-6549.v2n7p96-114

13. Gama ASM, Fernandes TG, Parente RCP, Secoli SR. A health survey in riverine communities in Amazonas State, Brazil. Cad Saúde Pública. 2018;34(2):e00002817. DOI: https://doi.org/10.1590/0102-311x00002817

14. Rocha DFNC, Rosa LRC, Silva CA, Oliveira BR, Martins TLS, Martins RMB, et al. Epidemiology of HIV, syphilis, and hepatitis B and C among manual cane cutters in low-income regions of Brazil. BMC Infect Dis. 2018;18(1):546. DOI: https://doi.org/10.1186/s12879-018-3439-4

15. de Amorim TF, Teles SA, Moraes LC, de Matos MA, dos Santos Carneiro MA, Nogueira DJ, et al. Symptomatic Sexually Transmitted Infections in Brazil's emerging rural populations. J Assoc Nurses AIDS Care. 2018;29(6):942-8. DOI: https://doi.org/10.1016/j.jana.2018.05.004

16. Brasil, Ministério da Saúde, Secretaria de Vigilância em Saúde, Departamento de DST, Aids e Hepatites Virais. Pesquisa de conhecimentos, atitudes e práticas na população brasileira [Internet]. Brasília: Ministério da Saúde; 2011. [cited 2020 July 03]. Available from: http://bvsms.saude.gov.br/ bvs/publicacoes/pesquisa_conhecimentos_atitudes_praticas_populacao_brasileira.pdf

17. Babor TF, Higgins-Biddle JC, Saunders JB, Monteiro MG. AUDIT - The Alcohol Use Disorders Identification Test: guidelines for use in Primary Care [Internet]. 2nd ed. Geneva: WHO; 2001 [cited 2020 Nov 2020]. Available from: https://apps.who.int/iris/handle/10665/67205

18. Brasil, Ministério da Saúde, Secretaria de Vigilância em Saúde, Departamento de DST, Aids e Hepatites Virais. HIV: Estratégias para utilização de testes rápidos no Brasil [Internet]. Brasília: Ministério da Saúde; 2010. [cited 2020 July 03]. Available from: http://bvsms.saude.gov.br/bvs/ publicacoes/HIV_estrategias_testes_rapidos_brasil.pdf

19. Siddiqi N. Credit risk scorecards: developing and implementing intelligent credit scoring. Hoboken: John Wiley \& Sons; 2006.

20. Rodrigues LLS, Hardick J, Nicol AF, Morgado MG, Martinelli KG, Paula VS, et al. Sexually transmitted infections among HIV-infected and HIVuninfected women in the Tapajós region, Amazon, Brazil: Self-collected vs. clinician-collected samples. PLoS One. 2019;14(4):e0215001. DOI: https://doi.org/10.1371/journal.pone.0215001

21. Ribeiro LVC, Sabidó M, Galbán E, Guerra JAO, Mabey D, Peeling RW, et al. Home-based counseling and testing for HIV and syphilis - An evaluation of acceptability and quality control, in remote Amazonas State, Brazil. Sex Transm Infect. 2015;91:94-6. DOI: https://doi.org/10.1136/ sextrans-2014-051625

22. Benzaken AS, Sabidó M, Brito I, Bermúdez XPD, Benzaken NS, Galbán E, et al. HIV and syphilis in the context of community vulnerability among indigenous people in the Brazilian Amazon. Int J Equity Health. 2017;16(1):92. DOI: https://doi.org/10.1186/s12939-017-0589-8

23. Douine M, Schaub R, Jardin H, Adenis A, Nacher M, Hureau-Mutricy L, et al. High prevalence of hepatitis B and syphilis in illegal gold miners in French Guiana. Clin Microbiol Infect. 2019;25(8):1051-3. DOI: https://doi.org/10.1016/j.cmi.2019.04.023

24. Brum MLB, Motta MGC, Zanatta EA. Bioecological systems and elements that make adolescents vulnerable to sexually transmissible infections. Texto \& Contexto Enfermagem. 2019;28:e20170492. DOI: https://dx.doi.org/10.1590/1980-265X-TCE-2017-0492

25. Kassie BA, Yenus H, Berhe R, Kassahun EA. Prevalence of sexually transmitted infections and associated factors among the University of Gondar students, Northwest Ethiopia: a cross-sectional study. Reprod Health. 2019;16:163. DOI: https://doi.org/10.1186/s12978-019-0815-5

26. Barros CVL, Galdino Junior H, Rezza G, Guimarães RA, Ferreira PM, Souza CM, et al. Bio-behavioral survey of syphilis in homeless men in Central Brazil: a cross-sectional study.Cad Saúde Pública. 2018;34(6):e00033317. DOI: https://doi.org/10.1590/0102-311X00033317 
27. Gomes NCRC, Meier DAP, Pieri FM, Alves E, Albanese SPR, Lentine EC, et al. Prevalence and factors with syphilis in a Reference Center. Rev Soc Bras Med Trop. 2017;50(1):27-34. DOI: https://doi.org/10.1590/0037-8682-0102-2016

28. Figueiredo GC, Faustino HH. Violence and social vulnerability: the impact of psychosocioeducative intervention in guaranteeing rights. Laplage em Revista 2018;4(3):225-39. DOI: https://doi.org/10.24115/S2446-6220201843533p.225-239

29. Bórquez C, Lobato I, Gazmuri P, Hurtado R, Llanqui V, Vivanco M, et al. Prevalence of HIV, hepatitis B virus and Treponema pallidum in inmates in the Preventive Detention Center of Arica, Chile. Rev Chil Infectol. 2017;34(5):453-7. DOI: http://dx.doi.org/10.4067/S0716-10182017000500453

30. Kai-Ju L, Zhang SK, Liu M, Wang QM, Liu J, Shen HP, et al. Seroepidemiology of syphilis infection among 2 million reproductive-age women in rural China: a population-based, cross-sectional study. Chin Med J (Engl). 2017;130(18):2198-204. DOI: http://dx.doi.org/10.4103/0366-6999.213975

\section{Financial support}

This work was carried out with the support of the Coordination for the Improvement of Higher Education Personnel - Brazil (CAPES) - Financing Code - 001. 